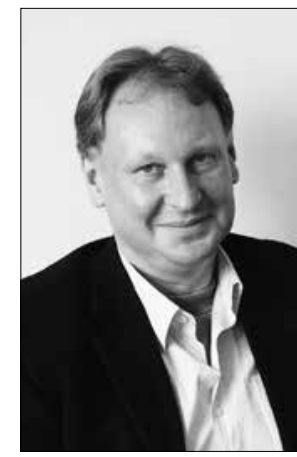

https://doi.org/10.24101/logos.2017.56

Gauta 20170619

TOMAS KAVALIAUSKAS

Vytauto Didžiojo universitetas, Lietuva

Vytautas Magnus University, Lithuania

\title{
NEUŽSIBAIGIANTI TRANZICIJA RYTŲ VIDURIO EUROPOJE: FILOSOFINE் GEOPOLITINIŲ IR SOCIOEKONOMINIŲ PERMAINŲ REFLEKSIJA
}

\author{
The Incompletable Transition in the East-Central Europe: \\ A Philosophical Reflection of Geopolitical \\ and Socioeconomic Shifts
}

\begin{abstract}
SUMMARY
This article analyzes changes in the postcommunist transition in the EU countries of East-Central Europe. The success story thesis is deconstructed as the author provides cases of social protests, socioeconomic injustice, shifts in geopolitical orientation, issues with the rule of law. However, when making a comparison of the quality of the transition that the EU countries of East Central Europe have made to the quality of the transition that Ukraine has made as a non-EU Eastern European country, then the thesis of success story becomes more believable.
\end{abstract}

\section{SANTRAUKA}

Šiame straipsnyje analizuojami pokomunistinės tranzicijos pokyčiai ES Rytų-Vidurio Europos šalyse. Sėkmės istorijos tezė dekonstruojama autoriui pateikiant socialinių protestų, socioekonominio neteisingumo, geopolitinės orientacijos pokyčių, teisės viršenybės problemų atvejus. Tačiau kai lyginame tranzicijos kokybę, kurią pasiekė ES Rytų-Vidurio Europos šalys, su tranzicijos kokybe, kurią pasiekė ne ES narẻ Ukraina kaip Rytų Europos šalis, tuomet sèkmès istorija tampa įtikinamesnè. 


\section{IVADAS}

Jacqueso Rupniko ese „The Euro Crisis: East-Central European Lessons" („Europos krizé: Rytų ir Vidurio Europos pamokos") - tai jo paties ankstesnio teksto nauja versija remiantis naujais ivykiais, nauju kontekstu. Sekant šio autoriaus pavyzdžiu, šis straipsnis taip pat yra atnaujintas variantas $2012 \mathrm{~m}$. publikuoto skyriaus apie tranziciją Rytu-Vidurio Europoje ${ }^{1}$. Praejus penkeriems metams, šiame Europos regione ivyko tokių svarbiu pokyčių, jog kai kurios ankstesnès išvados ir interpretacijos atsidūrè naujame geopolitiniame ir socialiniame kontekste.

Kalbant H.-G. Gadamerio terminais, esame naujame laiko horizonte, kuriam reikia naujos filosofinès refleksijos, naujų apmąstymu ir vertinimų. Pritariant Gadameriui, kad interpretuodami ivvyki ankstesniame laiko horizonte iš savojo laiko horizonto, mes sukuriame naujas prasmes, teigtina, jog šio straipsnio prasmès po keleriu metu, ypač ìvykus geopolitiškai svarbiems ivykiams, taip pat gali pasikeisti. Užuot pretendavę i galutinio tikslo žinojimą tranzitologijoje, kaip tai tvirtina Zenonas Norkus savo monografijoje Koks kapitalizmas? Kokia demokratija?² paskelbdamas konkrečią $2004 \mathrm{~m}$. datą kaip užbaigusią perèjimą „iš" sovietinio socializmo , i“ demokratiją šiame tekste teigiama, kad ne tik tranzicija Rytu-Vidurio Europoje yra neužsibaigianti, nes patiria transformacijas kintančiame kontekste, bet dar ỉvykusiu tranzicijos etapu prasmė nėra galutinè. Kaip buvo rašyta recenzijoje, skirtoje minètai Norkaus monografijai, būdamas paveiktas Gianni Vattimo hermeneutinès tiesos supratimo ${ }^{3}$, ,esu atviras geresnèms ateities interpretacijoms ir tam, kad rytoj mano interpretacija gali pasirodyti netgi naivi. Tik atlikęs ši savivokos judesi èmiausi savaip interpretuoti Vidurio Europos pokomunistinius pokyčius geopolitiniu, socioekonominiu ir kultūiniu rakursais. <...> tikiu, kad mano argumentai ir išvados tvirtos šiandien, bet noriu būti laisvas jas arba paneigti pats ateityje, arba priimti kitu kritika, arba patvirtinti dar karta, bet vèlgi tik laikinai. Mat svarbu nepamiršti, kad G. Vattimo hermeneutinę tiesą apibūdina kaip nihilistinę, nes nèra galutinès tiesos, nèra absoliučiai teisingos ir nekintamos epistemologijos. Tad, neneigdami geriausio argumento šiandiena, mes ji priimame su sąlyga, kad tai geriausia, ką turime, bet liekame atviri geresniam argumentui rytoj." ${ }^{4}<\ldots>$ juolab kad rytoj mūsų laukia nauji įvykiai, naujai nušviečiantys ankstesnių transformacijų prasmes. Traktuojant transfromacijas kaip sudarančias tranzicijos struktūrą, jos nauji pokyčiai skatina naują supratimą. 2017 m. Višegrado ketverto (Lenkija, Vengrija, Slovakija, Čekija) viršūniu pozicija išryškino ši regioną kaip oponuojantį Briuseliui, nors dar visai neseniai Milano Kunderos esè „The Tragedy of Central Europe ${ }^{\prime \prime}$ reiške, kad šis regionas cvilizaciškai yra provakarietiškas, o ne prorusiškas. Tačiau Višegrado viršūniu susitikime Viktoro Orbano pareiškimas, kad Europos šalys naujojo pasaulio tvarkoje turi rasti savo vieta, verčia klausti, kas tiksliai turima omenyje, ypač po to, kai Vladimiras Putinas apsilankè Budapešte. Tokia nauja Višegrado tapatybe 
keičia ne tik M. Kunderos Rytų-Vidurio Europos vaidmens prasmę, bet dar ir transformuoja didžiųu disidentų V. Havelo, A. Michniko sukurtą antirusišką ir provakarietišką liberalu diskursą. Višegrado nauja politika netgi transformuoja Prahos $1968 \mathrm{~m}$. antikomunistinę paradigmą tokią svarbią $1989 \mathrm{~m}$. išsivadavimo diskursui, ant kurio pamatu buvo pasirinktas kelias į ES narystę ir bendrą Šengeno zoną. 1989 m. išsivadavimo diskursas vaidino lemiamą vaidmeni ne tik siekiant Tarybų Sajungos žlugimo, bet ir geopolitiškai atsiribojant nuo Rusijos, civilizaciškai pasirenkant provakarietišką orientaciją su integracija i̇ ES ekonominę bei kultūrinę zoną. Tačiau Višegrado ketverto išreikštas reikalavimas ES sustiprinti išorinių sienų kontrolę terorizmo kontekste yra svarbus saugumo klausimas, kurị ima pripažinti ir kitų ES regionu šalys.

Ivykusi Krymo aneksija, taip pat ivykęs karas Rytų Ukrainoje kitaip nušviečia ar, geriau pasakius, pritemdo Kijevo revoliucinio Maidano pergalę. Šie Ukrainos ivykiai radikalizavo Baltijos šalių (Estijos, Latvijos, Lietuvos) santykius su Rusijos Federacija. Dar labiau išryškejjo Baltijos šalių vaidmuo NATO sudètyje, skirtingai nei vykdoma Viktoro Orbano politika. Po 2014 m., kada Vengrija ir Čekija tapo prorusiškos, ekonomiškai bendradarbiaujančios, ryškejja pokomunistinių šalių ivykdytos tranzicijos geopolitinis revizionizmas. Tai rodo, kad tranzicija tęsiasi ne linijiniu teleologiniu keliu. Bendro teloso netgi nèra, koki mes randame romantizuotame $1989 \mathrm{~m}$. išsivadavimo diskurse griūvant Berlyno sienai.

\section{RYTŲ VIDURIO EUROPOS REGIONO APSIBRĖŽIMAS}

Straipsnio pavadinime ivardijimas „Rytų-Vidurio Europa“ vietoje „Vidurio Europa" vartojamas tam, kad išvengtume nereikalingo nesusipratimo: Europos viduriui žymėti vartojamas terminas Mitteleuropa, o štai Milanas Kundera vartojo Vidurio Europos (angl. Central Europe) terminą taikydamas ji Višegrado šalims. Todèl šiame straipsnyje pridedamas žodis "Rytų" prie „Vidurio Europos" tam, kad žymètu skirtumą nuo tokios Vidurio Europos, kokią supranta šveicarai. Jiems Vidurio Europa reiškia rytinę Prancūzijos dali, pačią Šveicariją Austriją ir šiaurinę Italijos dalị $\mathfrak{c}^{6}$. Vengiant tokių nesusipratimu, šiame straipsnyje gilinamasi i pokomunistines ES šalis suprantant Rytų-Vidurio Europą plačiau, nei Kundera, kuris apsiribojo
Višegrado šalimis. Taikant kriteriju j, jog Baltijos šalys taip pat yra NATO ir ES šalys, o tokios yra Balkanų regione esančios Slovenija, Bulgarija ir Rumunija, Rytų-Vidurio Europa apims ir šias šalis greta Višegrado šalių ketverto - Čekijos, Slovakijos, Lenkijos, Vengrijos. Kitos svarbios šiam regionui šalys - Rusija, Ukraina, Baltarusija - paliekamos nuošaliau, nes ju pokomunistine tranzicija neatvedè iki narystės ES ir NATO. Pastarosios šalys veikiau būtų traktuojamos vien tik kaip „Rytu“ Europos šalys, o ne kaip „Rytu-Vidurio“ Europos. Kalbant Huntingtono civilizacinio riboženklio prasme, ši regioniniu „Rytų" ir "RytuVidurio" klasifikavimu skirtis atspindi skirtingas geopolitines orientacijas ir socioekonomini lygit. 


\section{RYTŲ-VIDURIO EUROPOS ŠALIŲ "SĖKMINGOS" TRANZICIJOS SĄLYGIŠKUMAS}

Nauji ivykiai, reikalingi naujos interpretacijos, rodo, kad kalbame apie "neužsibaigiančią tranziciją". Čia parinktas žodis "neužsibaigianti“ skiriasi nuo „nesibaigianti“. Pastaroji prasmè nurodo tik i laika, t. y. kad laiko požiūriu vis nesibaigia pereinamasis laikotarpis, tačiau žodis "neužsibaigianti“ turettu nurodyti dar ir galutinio rezultato nepasiekiamuma, t. y. kad tranzicija vis neužsidaro, vis nepasibaigia, nes atsiranda vis nauji jos tęsiniai, kurie naujai nušviečia ir transformuoja ankstesnius jos etapus.

Politinès ir socioekonominès transformacijos vyksta ne tik pažangos link, teleologiniu keliu, bet ir regresyviai bei spirale su šalutiniais poveikiais. Regresiniu socioekonominiu transformaciju pastaraisiais metais matėme Bulgarijoje, o antikorupcinès masinès demonstracijos, protestai Bukarešte taip pat rodo, kad vadinamoji tranzicija iš komunizmo i demokratiją kai kuriose šalyse vyksta su atbuline pavara. Būtina pridurti, kad šiandieninè Lenkijos vyriausybè, kontroliuojanti teismus, teisètai sulaukè perspèjimo iš Briuselio dèl teisès viršenybès - rule of law. Taip pat Slovėnijoje ivykusios demonstracijos, socialiniai protestai prieš elitą buvo lydimi slovènu nostalgijos buvusiai socialistinei Jugoslavijai. Tai taip pat liudija pokomunistinès transformacijos „sèkmès“ sąlygiškumą. Vladimiro Putino apsilankymas Slovenijoje $2016 \mathrm{~m}$. ir Vengrijoje $2017 \mathrm{~m}$. liudija ganètinai nesolidarų Rytų-Vidurio Europos šaliu geopolitini strategavima, nors šios dvi šalys yra NATO narès.

Žinoma, lygindami ES Rytų-Vidurio Europos šaliu geopolitines transformaci- jas su Ukrainos ar Baltarusijos, išvysime milžinišką skirtumą. Baltarusija yra stabili autoritarinè valstybe ir Rusijos satelite, jos teritorijoje i̇vyko ir karinès pratybos Zapad 2017. Baltarusijoje nevyksta jokių ženkliu transformacijų, palankių perèjimui i demokratiją. O Ukrainos méginimas ivveikti korumpuotą Janukovičiaus režimą pareikalavo Maidano aukų. Pomaidaninè Ukraina pasiekè bevizi statusą i ES šalis ir pakeite savo krypti Vakarų link neatsižvelgiant i Rusijos Federacijos sukeltą karinį konfliktą Rytu Ukrainoje. Ukrainos atveju kalbame apie visiškai kito lygmens neužsibaigiančią tranziciją nei ta, kuri turima omenyje kalbant apie ES Rytu-Vidurio Europos šalis.

Tačiau sèkmingos tranzicijos sąlygiškumą liudija ne tik geopolitine plotmè, bet ir socioekonominè padètis šalyse. Nuo 2012 m. lapkričio protestu pradžios tapo nebeaišku, ar Slovènija yra sèkmès atvejas, success story. Anot slovènu kultūrologo Mitjos Velikonja, Slovėnija yra sėkmės atvejis kurdama toki savo įvaiz$\mathrm{d} i \mathrm{i}$ o iš tikruju vyrauja jugonostalgija Tito režimui ${ }^{7}$.

Borisas Vezjakas straipsnyje "Slovenia's uprising" („Slovėnijos sukilimas") prideda tokią pastaba jog masinès demonstracijos visoje šalyje išreiške žmonių valią nesitaikstyti su esama padètimi, elito piktnaudžiavimu, kapitalistiniu gobšumu.

Z. Norkus galèjo būti daug atsargesnis beatodairiškai glorifikuodamas Slovẻnijos tranzitologinę sèkmę savo knygoje On Adriatic Lithuania and Baltic Slovenia (Apie Adrijos Lietuva ir Baltijos Slovenija). Kad geriau suprastume Sloveni- 
jos geštaltini ivvaizdžio ap(si)vertimą (geštalto paveikslèlyje turime atsakyti, ar laiptai kyla aukštyn, ar leidžiasi žemyn, ar taurè pusiau pilna, ar pusiau tuščia), Mitja Velikonja pasidalijo Slovènijos "progreso" samprata.

Slovenija sèkmingai įvykdè postsocialistinę tranziciją tik įtikinèdama kitus, kad tai - "success story“, kaip kad tame valdančiuju liberalų lozunge 10-ajame XX a. dešimtmetyje, arba kaip prieš kelerius metus dešiniujju partija tarè: „Rojus po Alpèmis.“ Tad kalbant apie "sėkmę“, arba apie "rojü", kai turime masini nedarba, korupcija gerovès valstybès griovima, išplitusį šovinizma, naujaji patriachalizma, partokratija, legalizuotą ir niekada nesankcionuotą "valstybès grobstymą", kur kadaise buvo kolektyvinè nuosavybė, etninius valymus (prisiminkime vadinamuosius „ištrintus žmones“, kai 25671 žmogus $1992 \mathrm{~m}$. buvo paliktas be legalaus statuso, nes jie buvo iš kitų buvusios Jugoslavijos šalių), neokolonializmo situaciją - ši šalis dabar atrodo kaip prastas anekdotas. $<$...> dauguma slovènu jaučiasi išduoti, apvogti, nusivylę - jie vis kartoja: „Ar jie dèl to kovojo?“ Besitęsiantys protestai Slovenijoje, kurie prasidejo 2012 m. lapkrití, ketina ištaisyti dvidešimt treju, dvidešimt ketverių metu klaidas: orientuojamasi prieš visus valdančiuosius elitus, kurie parklupde šali. Nesvarbu, ar kalbame apie dešiniuosius, ar apie liberalus, slovènu vyriausybès dalyvavo toje pačioje politineje praktikoje ir ideologiniame diskurse - svarbiausia buvo nacionalizmas ir neoliberalizmas - su mažais skirtumais. Jų nuostata dèl pažeidžiamiausių slovènų visuomenès grupiu - imigrantu, moteru, romu, bedarbiu vargšu, gëjų ir lesbiečiu, pabėgèliu - buvo praktiškai identiška. Šių grupių soci- alinè, politinè ar ekonominè padètis nepagerèjo. ${ }^{9}$

Antai tai, kad Latvijoje neišspręstas rusakalbių pilietybès klausimas, taip pat turi būti svarbu analizuojant tranzicijos kokybę. Kaip pažymejjo Arvydas Juozaitis, $2012 \mathrm{~m}$. vasario 18-osios referendumas nebūtų ìvykęs net su sovietinių tanku prievarta, jei ne dèl vykdomos Latvijos nacionalistu politikos. Radikali pastanga panaikinti visas rusiškas mokyklas Latvijoje, bet išsaugoti lietuviškas, lenkiškas, ukrainietiškas, sukèlè pasipiktinimą. Išpuolis prieš rusakalbius prasidèjo šūkiu Visu Latvijai! Bet juk dar nuo 2003 m. rusiškose mokyklose buvo reikalaujama daugiau kaip pusę dalykų mokyti latviškai. Tarytum to nepakaktu, buvo siekiama visiškai sunaikinti rusų kalbą ${ }^{10}$.

Denissas Hanovsas teigia, kad latviu nacionalistinė problema glūdi nenuoseklioje politineje valioje sukurti toki bendrą tarpkultūrinị dialoga, kuris apimtų platesnį Latvijos kultūrini paveldą. Anot jo, „vadinamosios dešiniosios partijos, kurios jau nuo 1990-ujų dominuoja politiniuose diskursuose, nesukūrè bendros viešos erdvès, kurioje įtraukimas (inclusion) būtų duominuojanti ideologija ir vertybè. Pagrindinè etninès politikos problema Latvijoje dèl ìvairių priežasčiu buvo ir tebèra latviu etninès praeities, atminties ir instituciju, simbolių ir objektų atkūrimas ${ }^{11}$.

Tad kaip galima vadinti sėkminga tranziciją iš komunizmo i̇ demokratiją, kada susiduriame su nesubalansuota dvikultūre ir dvitaute Latvija, kurioje rusakalbiu pilietybės klausimas vis dar neišspręstas nuo 1991m. įvykusio Latvijos nepriklausomybės atgavimo? Šiuo požiūriu Latvijos tranzicija niekada ir nebuvo pasibaigusi. 
Neužsibaigiančių transformacijų galime pastebèti ir kitu rakursu - pakitusioje savęs susideginimo paskirtyje. Iprastai Rytų-Vidurio Europos išsivadavimo diskursas įtraukia tokius idealistus, kurie susidegino už laisvę kovodami prieš diktatorišką komunistini režimą. Turime čekų herojų Janą Palacha, lietuvių Romą Kalanta, lenkų Richardą Siwiecą. Po stebuklingųu 1989 m., griuvus Berlyno sienai ir išvedus sovietinę armiją iš Rytų-Vidurio Europos, paskutiniojo dešimtmečio pradžioje niekas nebesusidegino už laisvę - ji buvo iškovota, nors ir lydima socioekonominių ir žmogaus teisių iššūkių. Tačiau idealistinis susideginimas ivvyko Bulgarijoje 2013 m. protestuojant prieš nepavykusią pokomunistinę tranziciją. Bulgaras Plamenas Goranovas susidegino protestuodamas konkrečiai prieš Bulgarijos kapitalizmo mafiją ir nepavykusią demokratija, kuri nesuteikè žadètosios laisvès.

Dimitaras Bechevas straipsnyje „Bulgarijos pyktis" teigia, kad Goranovo savižudybè igalino vietinius piliečius pakelti balsą prieš versla, tarnaujantį Borosovui, kuris kontroliuoja du trečdalius Varnos ekonomikos. Protestuojant prieš korupcija, taip pat buvo kritikuojama Bulgarijos visa pokomunistinè tranzicija, pats ekonomikos modelis ${ }^{12}$.

Toks nusivylimas nuvilnijo ir Bukarešto protestuose. $2017 \mathrm{~m}$. vasario mèn. minios protestuotujuc dvi savaites dieną ir nakti protestavo prieš korumpuotą Rumunijos vyriausybę. Tai kelia klausimą: kokia vis dèlto toji demokratijos kokybė Rumunijoje? Kokia jos tranzicijos Europos Sajungos sudètyje kokybè?

Tokie atvejai provokuoja naujas RytųVidurio Europos kaip regiono prasmes.
Prie tokių atveju pridejus Lietuvos itin sparčią emigracija, kuri net prilyginama evakuacijai, matant tautos išsi-kraustyma ši kartą savanoriška, kyla klausimas dèl sèkmingos tranzicijos sampratos: kas turi būti suprantama kaip sėkmè? Filosofiškai galima klausti: kokia yra ontologinè, t. y. büties lygmenyje, tautos sèkmé, kai ji demokratijos sąlygomis išsikrausto? Kritiškai analizuodami vykstančias transformacijas matome, kad klaidinga laikytis teleologinio „sėkmingos" tranzicijos iš/i pasakojimo.

Kas, jei linijinis teleologinis pokomunistinès tranzicijos pažangos pasakojimas tinka tik didesniame ES evoliucijos cikle? Anot Jacqueso Rupniko, dabar mes galime žvelgti atgalios ir matyti pirmuosius dvidešimt tranzicijos metų Rytų-Vidurio Europoje. Matome, kad tikslas konsoliduoti demokratiją (consolidated democracy) pasiektas. Tačiau demokratija išgyvena krizę, o Europa yra pavargusi, nežinanti savo krypties, kurią žinojo $1989 \mathrm{~m}$. ir vis dar žinojo $2004 \mathrm{~m}$. Po 2008 m. finansinès krizès kyla jausmas, kad ciklas yra užbaigtas ir yra išsisemta ${ }^{13}$.

Kita vertus, kada lyginame ES RytųVidurio Europos šalis su ne ES Rytų Europos šalimis, matome skirtingą socialinio neteisingumo ir oligarchinio elito mastą. Yra skirtumu tarp Lenkijos ir Rumunijos, Estijos ir Bulgarijos; dar radikalesni atotrūkiai, išsivystymo skirtumai, socioekonominiai kontrastai randami lyginant Ukrainos tranzicijos problemas su Europos Sajungai priklausančiomis Rytų-Vidurio Europos šalimis. Euromaidanas parodè, kaip sunku Ukrainai užbaigti niekada nesibaigiančią pokomunistinę tranziciją visai kitame lygyje nei tas, kuriame pokomunistine tranzicija neužsibaigia ES Rytų-Vidurio Europoje. 


\section{IŠVADOS}

Krymo aneksija ir karas Rytų Ukrainoje 2014 m. atskleidè, kokios gali būti pasekmès, kai šalis revoliucingai keičia savo geopolitinę kryptį. Tokiu karinių konfliktų su Rusija pavyko išvengti Baltijos šalims stojant i NATO ir ES $2004 \mathrm{~m}$. Tai turètu būti traktuojama ne kaip savaime suprantamas laimèjimas, o kaip geopolitinè sèkmès istorija. Šiuo požiūriu ir pokomunistinè tranzicija vertintina kaip sèkmès istorija, kuri sutampa su Z. Norkaus teleologine pozicija. Tačiau esant karo grèsmei, ši sèkmingos tranzicijos tezè yra trapi, sąlygiška. Kaip Antrasis pasaulinis karas ir po to vykusi sovietinė okupacija Baltijos šalyse nušlavè tarpukario pirmosios nepriklausomybès laimèjimus, taip i̇vyktų ir sẻkmingai geopolitinei tranzicijai naujo karo atveju. Tuomet atsirastų naujas aiškinimas apie

\section{Literatūra ir nuorodos}

1 Tomas Kavaliauskas, Transformations in EastCentral Europe between 1989 and 2012: geopolitical, cultural, and socioeconomic shifts. Lexington Books, 2012.

2 Zenonas Norkus, Koks kapitalizmas? Kokia demokratija? Vilnius: Universiteto leidykla, 2008.

3 Gianni Vattimo, Beyond Interpretation. Stanford University Press, 1997.

4 Tomas Kavaliauskas, Recenzija: Apie Zenono Norkaus teleologini mąstymą klausiant: ar Vidurio Europoje pokomunistinè transformacija jau užbaigta? Darbai ir dienos 58, 2012, p. 323-334.

5 Milan Kundera, The Tragedy of Central Europe.

${ }^{6}$ Christian Giordano, Western Europe and the rest of it: the Swiss perspective. T. Kavaliauskas (sudarytojas ir vertejas), Conversations about Transcultural European Memory / Pokalbiai apie transkultūrinę Europos atmintị. Vilnius: Edukologija, 2013.

7 Mitja Velikonja, Slovenian Yugonostalgia and its alternative culture. Ten pat, p. 81.

8 Boris Vezjak, Slovenia's Uprising. Dialogi 9, 2012 pokomunistinę tranziciją. Metaforiškai kalbant, kaip keičiasi žmogaus savęs suvokimas po netikèto tragiško įvykio saulètą dieną, taip keičiasi ir Europos šalių sėkmès aiškinimas, kai po taikos nugriaudèja pirmieji tankų šūviai.

Taikos sąlygomis teleologinè sėkmès tezė Rytų-Vidurio Europoje skamba įtikinamiau palyginti su Rytu Europa, su tokiomis ES nepriklausančiomis šalimis kaip Ukraina ar Moldova. Vis dèlto šiame straipsnyje aptarta Rytu-Vidurio Europoje vykstančiu socialiniu protestu gausa, socioekonominiu netolygumu kontrastai, Višegrado geopolitinès tapatybès transformacijos ir išsivadavimo diskurso modifikavimas, euroskepticizmas, didejantis nacionalizmas ir tautos išsikraustymas (ypač Lietuvos atveju) verčia permąstyti ivykusias ir tebevykstančias kaitas.

(Slovenian version). Prieiga per internetą: http:// www.eurozine.com/articles/2013-01-10-vezjaken.html

${ }^{9}$ Mitja Velikonja, Slovenian Yugonostalgia and its alternative culture, p. 253.

10 Arvydas Juozaitis, Rusų kalba - antroji valstybinė? [Russian Language - The Second State Language?] Literatūra ir menas 6, Nr. 3336, p. 13.

11 Deniss Hanovs, Latvia's asymmetric memory and politics of divided ethnicity. T. Kavaliauskas (sudarytojas ir vertejas), Conversations about Transcultural European Memory / Pokalbiai apie transkultūrinę Europos atmintị. Vilnius: Edukologija, p. 66-67.

12 Dimitar Bechev, Bulgaria's anger. First published in open Democracy 1403 2013. Prieiga per internetą: http://www.eurozine.com/articles/201303-21-bechev-en.html

13 Jacques Rupnik, Speech at Symposium in Honour of Claus Offe. Liberal Democracy in Hard Times: Transitions, Dilemmas, and Innovation. Hertie School of Governance, Berlin, 22 March, 2012. 